\title{
Optimasi produksi kedelai (Glycine max L. Merr) melalui aplikasi pupuk hayati dan budidaya jenuh air di lahan rawa
}

\author{
Optimizing productivity of soybean (Glycine max, L. Merr) through biofertilizer \\ application and saturated soil cultivation on swampland \\ Bariot $\mathrm{HAFIF}^{1)^{*}}$ \& Laksmita Prima SANTI ${ }^{2)}$ \\ ${ }^{1)}$ Balai Pengkajian Teknologi Pertanian Lampung, Jl. Zainal Abidin Pagar Alam No.1A, Bandar Lampung 35144, \\ Indonesia \\ 2) Pusat Penelitian Bioteknologi dan Bioindustri Indonesia, J1. Taman Kencana No. 1, Bogor 16128, Indonesia
}

Diterima tgl 18 Mei 2016/ disetujui tgl 24 Desember 2016

\begin{abstract}
Tidal swampland is a marginal land that has significant potentials for the development of food crops, although its exploration will face several constraints such as low $\mathrm{pH}$, high content of iron $\left(\mathrm{Fe}^{2+}\right)$, low phosphorus $(\mathrm{P})$, shallow pyrite $\left(\mathrm{FeS}_{2}\right)$ layer, high salinity, and excess water. The objective of this study was to investigate the effect of biofertilizer and saturated soil cultivation in improving nutrient use efficiency and productivity of soybean in the tidal swamp. The field experiment was arranged in a splits plot design with $2 \times 3 \times 4$ treatments and 3 replications respectively. The treatment in the main plot was soybean cultivation techniques (B) consisting of farmer's cultivation method (B1) and saturated soil cultivation (B2). The subplot treatment was soybean superior varieties consisting of Anjasmoro (V1), Argomulyo (V2) and Grobogan (V3) and the sub-subplot treatment was fertilization $(P)$ consisting of a $100 \%$ of standard dose of NPK (P1) and the use of biofertilizer (1 $\mathrm{kg}$ ) combined with NPK; 100\% of standard dose (P2), 75\% of the standard dose (P3), and 50\% of the standard dosages (P4) per hectare. The results showed that Bradyrhizobium japonicum R6 and Aeromonas punctata RJM3020 as an active ingredient of biofertilizer was effective to reduce chemical fertilizer NPK up to $50 \%$ of the standard dose commonly applied to soybean cultivation by farmers. Anjasmoro varieties treated with this biofertilizer and combined with $50 \%$ of standard dosages of NPK could produce up to $2.798 \mathrm{~kg}$ of dry beans/ha under saturated soil cultivation.
\end{abstract}

[Keywords: soybean, biofertilizer, saturated soil cultivation, tidal swamp]

\section{Abstrak}

Lahan rawa pasang surut merupakan lahan marginal yang memiliki potensi cukup besar untuk pengembangan pertanian tanaman pangan, meskipun dalam pemberdayaannya berhadapan dengan beberapa kendala seperti $\mathrm{pH}$ tanah rendah,

\footnotetext{
*) Penulis korespondensi: hafif_bariot@yahoo.co.id
}

kandungan besi $\left(\mathrm{Fe}^{2+}\right)$ tinggi, kandungan fosfor (P) rendah, lapisan pirit $\left(\mathrm{FeS}_{2}\right)$ relatif dangkal, kadar salinitas tinggi, dan volume air berlebih. Tujuan penelitian ini adalah menguji kemampuan pupuk hayati dan budidaya jenuh air dalam memperbaiki efisiensi penggunaan hara dan produktivitas kedelai di lahan rawa pasang surut. Percobaan lapang menggunakan rancangan petakpetak terpisah dengan perlakuan $2 \times 3 \times 4$ dan masing-masing diulang 3 kali. Sebagai petak utama ialah teknik budidaya kedelai (B) yang terdiri atas budidaya cara petani (B1) dan budidaya jenuh air (B2). Perlakuan pada anak petak yaitu kedelai varietas unggul baru (VUB) yang terdiri atas Anjasmoro (V1), Argomulyo (V2) dan Grobogan (V3). Sedangkan perlakuan pada anak-anak petak adalah pemupukan $(\mathrm{P})$ yang terdiri atas NPK $100 \%$ dosis standar (P1), dan penggunaan $1 \mathrm{~kg}$ pupuk hayati yang dikombinasi dengan NPK; 100\% dosis standar (P2), 75\% dosis standar (P3), dan 50\% dosis standar (P4) per hektar. Hasil penelitian memperlihatkan penggunaan Bradyrhizobium japonicum R6 dan Aeromonas punctata RJM3020 sebagai bahan aktif pupuk hayati dapat menghemat penggunaan pupuk kimia NPK sampai dengan $50 \%$ dari dosis standar yang biasa diaplikasikan petani untuk budidaya kedelai. Di dalam sistem budidaya jenuh air, kedelai varietas Anjasmoro yang diperlakukan dengan pupuk hayati dengan kombinasinya menggunakan pupuk NPK 50\% dari dosis standar dapat menghasilkan biji kering sampai dengan $2.798 \mathrm{~kg} / \mathrm{ha}$.

[Kata kunci: kedelai, pupuk hayati, budidaya jenuh air, lahan rawa pasang surut]

\section{Pendahuluan}

Lahan rawa merupakan lahan marginal yang memiliki potensi cukup baik untuk dikelola menjadi areal pertanian termasuk pertanian tanaman pangan. Di Indonesia luas lahan rawa pasang surut sekitar 20,1 juta hektar dan sekitar 9,9 juta hektar diantaranya berpotensi untuk ekstensifikasi lahan (Haryono, 2013). 
Sementara itu, luas lahan rawa di Provinsi Lampung sekitar 104.455 ha (Sudaryanto et al., 2002). Pada tahun 2013 luasan lahan rawa yang belum digarap di daerah ini tinggal 35.132 ha yang terdiri atas rawa 29.732 ha dan tanggul sepanjang alur pasang surut seluas 5.400 ha (Sukarman et al., 2013).

Pemanfaatan lahan rawa pasang surut untuk pengembangan tanaman pangan terkendala pada sifat fisika, kimia, dan biologi tanah sebagai faktor pembatas pertumbuhan tanaman, seperti $\mathrm{pH}$ rendah, kandungan besi $\left(\mathrm{Fe}^{2+}\right)$ tinggi, kandungan $\mathrm{P}$ rendah, lapisan pirit $\left(\mathrm{FeS}_{2}\right)$ relatif dangkal, kadar salinitas tinggi dan volume air berlebih (Achmadi \& Las, 2006; Nazemi et al., 2012) serta rendahnya populasi mikroorganisme tanah. Selain itu, tanah lahan rawa yang telah dibuka dan dimanfaatkan di daerah tropik secara umum kandungan haranya cepat menurun (Ismawi et al., 2012; Könönen et al., 2015).

Salah satu strategi untuk meningkatkan ketersediaan hara di tanah rawa ialah dengan mengaplikasikan pupuk hayati. $B$. japonicum R6 dan $A$. punctata RJM3020 merupakan bakteri yang digunakan sebagai bahan aktif pupuk hayati (Goenadi \& Santi, 2009). B. japonicum R6 merupakan kelompok bakteri penambat nitrogen yang bersimbiosis dengan perakaran kacangkacangan serta efektif dalam pembentukan nodul pada perakaran kedelai (Noh et al., 2015; Amel et al., 2014). Hasil penelitian Hungria et al., (2006) mendapatkan bahwa B. japonicum dapat meningkatkan kemampuan kedelai dalam memfiksasi $\mathrm{N}_{2}$ sampai $300 \mathrm{~kg} \mathrm{~N} / \mathrm{ha}$. Penggunaan Bradyrhizobium di lahan rawa pasang surut yang diberi kapur di Sumatera Selatan, mampu meningkatkan produksi kedelai sampai 161\% (Forum for Nuclear Cooperation in Asia 2005). A. punctata RJM 3020 adalah bakteri pelarut fosfat (phosphate solubilizing bacteria) yang dapat meningkatkan ketersediaan hara terutama $\mathrm{P}$ di dalam tanah dan memantapkan stabilitas agregat tanah (Goenadi \& Santi, 2009). Penggunaan bakteri pelarut fosfat diharapkan mampu meningkatkan ketersediaan hara $\mathrm{P}$ di lahan rawa pasang surut karena ketersediaan $\mathrm{P}$ di lahan tersebut rendah dan kebanyakan dalam bentuk P organik (Andriesse, 1988).

Budidaya jenuh air merupakan penanaman dengan dukungan ketersediaan air melalui penjenuhan lapisan tanah secara terus menerus. Pada lahan pasang surut kelebihan air dianggap sebagai salah satu kendala dalam pemanfaatan lahan untuk budidaya tanaman pangan (Lakitan \& Govar, 2013). Penerapan cara pengelolaan yang tepat diharapkan dapat mengubah tantangan itu menjadi suatu peluang (Haryono, 2013). Salah satunya ialah melalui penerapan budidaya jenuh air yang mampu memperbaiki pertumbuhan dan meningkatkan produksi kedelai di lahan rawa (Ghulamahdi et al., 2009; Ghulamahdi, 2011; Sahuri \& Ghulamahdi, 2014). Hasil penelitian ini memaparkan penggunaan pupuk hayati yang dikombinasikan dengan pupuk NPK di dalam teknik budidaya jenuh air untuk meningkatkan efisiensi pemupukan dan produktivitas kedelai varietas unggul baru (VUB) di lahan rawa pasang surut.

\section{Bahan dan Metode}

\section{Mikroorganisme}

Dua jenis bakteri yang digunakan sebagai bahan aktif untuk kegiatan riset di lapang ini adalah $B$. japonicum R6 dan $A$. punctata RJM3020. Bakteri tersebut merupakan koleksi biakan di Pusat Penelitian Bioteknologi dan Bioindustri Indonesia (PPBBI), Bogor. Berdasarkan hasil kegiatan riset terdahulu (Goenadi \& Santi, 2009), kedua biakan ini telah terbukti dapat meningkatkan produksi kedelai di lahan marginal. Dua bakteri bahan aktif ini dapat tumbuh pada $\mathrm{pH}$ tanah dengan kisaran 4,0-9,0. B. japonicum R6 dipelihara dalam agar miring berisi medium padat yeast mannitol agar (YMA) dengan komposisi (per liter medium): $10 \mathrm{~g}$ Mannitol; 0,5 g K ${ }_{2} \mathrm{HPO}_{4}$; 0,5 g ekstrak khamir; 0,2 g MgSO$_{4} .7 \mathrm{H}_{2} \mathrm{O} ; 0,1 \mathrm{~g} \mathrm{NaCl} ; 0,25 \%$ congo red $(10 \mathrm{~mL}) ; 1 \mathrm{~L}$ akuades, $15 \mathrm{~g}$ agar bacto dan $\mathrm{pH}$ diatur menjadi $6,8 \pm 0,2$ pada temperature $25^{\circ} \mathrm{C}$. Sementara itu $A$. punctata JM3020 ditumbuhkan dalam medium Pikovskaya dengan komposisi (per liter medium): $10 \mathrm{~g}$ glukosa; $0,2 \mathrm{~g} \mathrm{NaCl} ; 0,1 \mathrm{~g}$ $\mathrm{KCl} ; 0,1 \mathrm{~g} \mathrm{MgSO}_{4} .7 \mathrm{H}_{2} \mathrm{O} ; 0,004 \mathrm{~g} \mathrm{MnSO}_{4} . \mathrm{H}_{2} \mathrm{O}$; $0,002 \mathrm{~g} \mathrm{FeSO}_{4} .7 \mathrm{H}_{2} \mathrm{O} ; 5 \mathrm{~g} \mathrm{Ca}_{3}\left(\mathrm{PO}_{4}\right)_{2} ; 0,5 \mathrm{~g}$ $\left(\mathrm{NH}_{4}\right)_{2} \mathrm{SO}_{4} ; 0,5 \mathrm{~g}$ ektrak khamir, $15 \mathrm{~g}$ agar bacto, $1 \mathrm{~L}$ akuadest dan $\mathrm{pH}$ diatur menjadi 7,2 $\pm 0,2$ pada temperatur $25^{\circ} \mathrm{C}$. Perbanyakan $B$. japonicum R6 dan $A$. punctata RJM3020 masing-masing dilakukan dalam medium cair YMA dan Pikovskaya, dengan masa inkubasi 72 jam pada temperatur ruang. Selanjutnya kedua kultur bakteri tersebut diinokulasikan ke dalam bahan pembawa campuran gambut dan zeolit (1:3) yang sebelumnya sudah dipasteurisasi terlebih dahulu. Untuk keperluan aplikasi, populasi masingmasing inokulan minimal $10^{7}$ cfu per gram bahan pembawa.

\section{Lokasi dan rancangan percobaan}

Penelitian dilaksanakan di areal persawahan lahan rawa pasang surut di Kecamatan Sragi, Kabupaten Lampung Selatan. Secara geografis lokasi penelitian lebih kurang terletak pada $105^{\circ} 45^{\prime} 57^{\prime}$ ' Bujur Timur dan 5'37'11' Lintang Selatan. Tanah di areal lahan rawa ini termasuk dalam subgroup Endoaquepts dan sebagian Sulfaquepts (Bahri et al., 2004). Hasil analisis 
kimia tanah yang disajikan pada Tabel 1 menunjukkan reaksi tanah kategori masam $(\mathrm{pH}$ 5,2), C-organik dan $\mathrm{N}$ kategori rendah, $\mathrm{P}$ potensial kategori sedang, $\mathrm{K}$ potensial kategori rendah, kation $\mathrm{K}$ dan $\mathrm{Ca}$ dapat ditukar kategori sedang dan $\mathrm{Mg}$ dapat ditukar kategori tinggi, kejenuhan basa kategori tinggi dan kejenuhan aluminium kategori rendah (Sulaeman et al., 2015). Total curah hujan tahunan di daerah ini berkisar 1700 - $2000 \mathrm{~mm}$ dengan curah hujan pada bulan basah (November-April) $1.000 \mathrm{~mm}$ dan pada bulan kering (April - November) $750 \mathrm{~mm}$ (Nurhayati et al., 2010). Rata-rata suhu udara $26,0-26,9{ }^{\circ} \mathrm{C}$ dengan kelembaban udara $77,0-84,5 \%$.

Penelitian menggunakan rancangan petakpetak terpisah (split-split plot design). Sebagai petak utama adalah teknik budidaya kedelai (B) yang terdiri atas budidaya konvensional oleh petani setempat (B1) dan budidaya jenuh air (B2) yaitu melakukan penjenuhan siring-siring yang dibuat pada lahan penanaman kedelai berukuran; dalam $30 \mathrm{~cm}$ dan lebar $25 \mathrm{~cm}$ dengan jarak antar siring $2 \mathrm{~m}$. Penjenuhan sampai muka air sekitar $15 \mathrm{~cm}$ dari permukaan tanah dilakukan dengan bantuan pompa air. Pengontrolan perlakuan dilakukan setiap 3 hari untuk mengembalikan tinggi muka air ke batas $15 \mathrm{~cm}$ dari permukaan tanah. Proses penjenuhan air tanah dimulai dari saat tanam sampai warna polong kedelai kecokelatan.

Sebagai anak petak yaitu kedelai varietas unggul baru (VUB) (V) yang terdiri atas kedelai varietas Anjasmoro (V1), Argomulyo (V2) dan Grobogan (V3). Perlakuan pada anak-anak petak terdiri atas pemupukan (P) yakni NPK 100\% dosis standar (P1), dan penggunaan pupuk hayati $1 \mathrm{~kg}$ untuk melapisi $25 \mathrm{~kg}$ benih kedelai yang masing-masing dikombinasi dengan NPK; 100\% dosis standar (P2), 75\% dosis standar (P3), dan $50 \%$ dosis standar (P4). Adapun dosis standar pupuk NPK untuk penanaman kedelai di lokasi ini adalah: $100 \mathrm{~kg}$ Urea/ha, $150 \mathrm{~kg}$ SP-36/ha dan $50 \mathrm{~kg} \mathrm{KCl} / \mathrm{ha}$. Pupuk NPK diaplikasi 1 kali secara serempak saat 3 hari sesudah tanam kedelai. Penanaman kedelai dilakukan dengan cara ditugal dan biji kedelai dibenamkan 2-3 biji per lubang tanam. Ukuran anak-anak petak masing-masing 10 × $20 \mathrm{~m}$. Dua minggu sebelum perlakuan, tanah diberi kapur dolomit sebanyak 1,5 ton/ha. Dosis pemberian kapur ini didasarkan atas pengukuran $\mathrm{pH}$ pada tanah rawa (Balai Penelitian Pertanian Lahan Rawa, 2012).

Analisis tanah dilakukan kembali setelah perlakuan dan mencakup kadar C-organik, N total, $\mathrm{P}$ tersedia dan $\mathrm{K}$ dapat dipertukarkan berdasarkan metoda yang dikemukakan oleh Sulaeman et al., (2005). Sementara itu, keragaan pertumbuhan kedelai dilihat melalui peubah: hasil biji kering $(\mathrm{kg} / \mathrm{ha})$, tinggi tanaman $(\mathrm{cm})$, jumlah polong (buah), dan bobot 100 biji (g). Data yang dikumpulkan selanjutnya dianalisis secara statistik menggunakan program SPSS. Uji lanjut (post hoc) dengan uji jarak ganda Duncan pada taraf nyata 1 dan $5 \%$.

\section{Hasil dan Pembahasan}

\section{Pengaruh perlakuan}

Penanaman kedelai pada lahan rawa pasang surut dengan mengelola air secara tepat, menggunakan varietas yang sesuai kondisi agroekologi dan dosis pupuk beserta kombinasinya yang tepat, diharapkan mampu meningkatkan produktivitas tanaman dan memperdayakan lahan yang tersedia untuk

Tabel 1. Beberapa sifat kimia tanah sawah lahan rawa pasang surut Lampung Selatan.

Table 1. Selected chemical properties of rice-field soil in the tidal swampland in South Lampung.

\begin{tabular}{|c|c|c|c|}
\hline $\begin{array}{c}\text { Peubah } \\
\text { Parameter }\end{array}$ & $\begin{array}{c}\text { Contoh } 1 \\
\text { (Sample1) }\end{array}$ & $\begin{array}{c}\text { Contoh } 2 \\
\text { (Sample 2) }\end{array}$ & $\begin{array}{c}\text { Rata-rata } \\
\text { (Average) }\end{array}$ \\
\hline \multirow{2}{*}{$\begin{array}{l}\mathrm{H}_{2} \mathrm{O} \\
\mathrm{KCl}\end{array}$} & 5,2 & 5,2 & 5,2 \\
\hline & 4,7 & 4,8 & 4,8 \\
\hline $\mathrm{C}($ Total C) $(\%)$ & 1,2 & 1,0 & 1,1 \\
\hline $\mathrm{N}($ Total N) $(\%)$ & 0,09 & 0,14 & 0,11 \\
\hline $\mathrm{P}\left(\right.$ Potential P) $\left(\mathrm{mg} \mathrm{P}_{2} \mathrm{O}_{5} / 100 \mathrm{~g}\right)$ & 29,5 & 18,2 & 23,8 \\
\hline $\mathrm{K}($ Potential $\mathrm{K})\left(\mathrm{mg} \mathrm{K}_{2} \mathrm{O} / 100 \mathrm{~g}\right)$ & 10,5 & 13,8 & 12,1 \\
\hline \multicolumn{4}{|l|}{ (Exchangeable cations) } \\
\hline $\mathrm{K}\left(\mathrm{cmol}_{(+)} / \mathrm{kg}\right)$ & 0,5 & 0,4 & 0,5 \\
\hline $\mathrm{Na}\left(\mathrm{cmol}_{(+)} / \mathrm{kg}\right)$ & 0,9 & 0,7 & 0,8 \\
\hline $\mathrm{Ca}\left(\mathrm{cmol}_{++} / \mathrm{kg}\right)$ & 6,9 & 5,8 & 6,4 \\
\hline $\operatorname{Mg}\left(\mathrm{cmol}_{(++} / \mathrm{kg}\right)$ & 2,8 & 2,9 & 2,9 \\
\hline $\mathrm{Al}\left(\mathrm{cmol}_{(+)} / \mathrm{kg}\right)$ & 0,4 & 0,3 & 0,3 \\
\hline $\mathrm{H}\left(\mathrm{cmol}_{(+)} / \mathrm{kg}\right)$ & 0,8 & 0,6 & 0,7 \\
\hline $\mathrm{KTK}(C E C)\left(\mathrm{cmol}_{(+)} / \mathrm{kg}\right)$ & 18,5 & 14,9 & 16,7 \\
\hline Kejenuhan basa (Base saturation) (\%) & 59,9 & 66,6 & 63,3 \\
\hline Kejenuhan aluminium (Al saturation) $(\%)$ & 3,4 & 3,2 & 3,3 \\
\hline
\end{tabular}


pertanian di Provinsi Lampung pada khususnya. Berdasarkan hasil riset lapangan ini diketahui perlakuan teknis budidaya (B) dan kedelai VUB (V) berpengaruh sangat nyata $(\mathrm{p} \leq 0,01)$ terhadap hasil biji, tinggi tanaman, jumlah polong dan bobot $100 \mathrm{~g}$ biji kering kedelai. Interaksi antara B dan $\mathrm{V}$ berpengaruh sangat nyata $(\mathrm{p} \leq 0,01)$ terhadap hasil biji dan berpengaruh nyata $(\mathrm{p} \leq 0,05)$ terhadap jumlah polong. Perlakuan cara pemupukan (P) berpengaruh sangat nyata $(\mathrm{p} \leq 0,01)$ terhadap tinggi tanaman (Tabel 2). Demikian pula interaksi antara $\mathrm{V}$ dan $\mathrm{P}$ berpengaruh nyata $(p \leq 0,05)$ terhadap tinggi tanaman. Sementara interaksi antara B dengan V dan $P$ tidak berpengaruh nyata terhadap variabelvariabel respon tersebut.

\section{Keragaan pertumbuhan tanaman kedelai}

Kedelai VUB Anjasmoro secara genetik memiliki potensi tinggi tanaman yang lebih tinggi dibandingkan dengan varietas Argomulyo dan
Grobogan. Namun dalam menghasilkan polong per tanaman ditentukan oleh interaksi antara faktor genetik dan lingkungan tumbuhnya seperti kesuburan tanah, ketersediaan air dan cara pengelolaan tanaman (Suhartina, 2005). Kedelai VUB Anjasmoro mampu beradaptasi secara baik dengan karakteristik agroekologi lahan rawa, salah satunya kondisi jenuh air (Ghulamahdi 2011; Ghulamahdi et al., 2012).

Dari uji statistik diketahui beberapa perlakuan pemupukan (P1, P2, P3, dan P4) dan interaksinya dengan kedelai VUB berpengaruh nyata terhadap tinggi tanaman dan tidak nyata terhadap jumlah polong pada ketiga kedelai VUB (Tabel 2). Ratarata tinggi tanaman kedelai pada perlakuan P2 (pupuk hayati + NPK 100\% dosis standar) lebih tinggi dibandingkan pada perlakuan pemupukan lainnya. Hal itu mengindikasikan pertumbuhan tanaman kedelai khususnya tinggi tanaman dipengaruhi oleh ketersediaan hara di dalam tanah. Namun demikian produksi dan jumlah

Tabel 2. Rata-rata produksi, tinggi, jumlah polong dan bobot 100 butir biji kedelai VUB dengan perlakuan pupuk hayati dan perbedaan teknik budidaya di lahan rawa pasang surut Lampung Selatan.

Table 2. The average yield, height, number of pods and weight of 100 seeds of superior soybean varieties treated with biofertilizer and different cultivation in the tidal swampland in South Lampung.

\begin{tabular}{|c|c|c|c|c|}
\hline \multirow[b]{2}{*}{ Perlakuan (Treatments) } & \multicolumn{4}{|c|}{$\begin{array}{c}\text { Variabel respon } \\
\text { (Response variable) }\end{array}$} \\
\hline & $\begin{array}{c}\text { Hasil } \\
\text { (Yield) } \\
(\mathrm{kg} / \mathrm{ha})\end{array}$ & $\begin{array}{c}\text { Tinggi } \\
(\text { Height }) \\
(\mathrm{cm})\end{array}$ & $\begin{array}{c}\text { Polong } \\
\text { Pod numbers) }\end{array}$ & $\begin{array}{l}\text { Bobot } 100 \\
\text { biji }(100-\text { seed } \\
\text { weight }) \\
(\mathrm{g})\end{array}$ \\
\hline \multicolumn{5}{|l|}{ Teknis Budidaya (Cultivation) (B) } \\
\hline - Cara petani (Farmers method) (B1) & 850,6 & 42,4 & 22,8 & 19,2 \\
\hline - Budidaya jenuh air (Saturated soil) (B2) & 1140,8 & 44,2 & 20,5 & 20,4 \\
\hline Sig. & 0,000 & 0,009 & 0,007 & 0,002 \\
\hline \multicolumn{5}{|l|}{ Kedelai VUB (Soybean variety) $(\mathrm{V})$} \\
\hline - Anjasmoro (V1) & 1235,1 & 50,1 & 29,2 & 19,8 \\
\hline - Argomulyo (V2) & 1079,9 & 44,7 & 17.8 & 17,7 \\
\hline - Grobogan (V3) & 672,1 & 35,2 & 18,0 & 21,8 \\
\hline Sig. & 0,000 & 0,000 & 0,000 & 0,000 \\
\hline \multicolumn{5}{|l|}{ Pemupukan (Fertilizing) (P) } \\
\hline - $\mathrm{P} 1$ & $1.012,9$ & 44,7 & 21,7 & 20,1 \\
\hline - $\quad \mathrm{P} 2$ & $1.012,7$ & 45,0 & 23,0 & 19,5 \\
\hline - $\quad \mathrm{P} 3$ & 959,7 & 41,7 & 20,1 & 19,6 \\
\hline - $\mathrm{P} 4$ & 997,3 & 41,9 & 21,9 & 19,9 \\
\hline Sig. & 0,934 & 0,001 & 0,088 & 0,503 \\
\hline \multicolumn{5}{|l|}{ ANOVA } \\
\hline - $\quad \mathrm{B}^{*} \mathrm{~V}$ & $* *$ & $\mathrm{TN}$ & $* *$ & $\mathrm{TN}$ \\
\hline - $\quad \mathrm{B} * \mathrm{P}$ & $\mathrm{TN}$ & $\mathrm{TN}$ & $\mathrm{TN}$ & $\mathrm{TN}$ \\
\hline - $\mathrm{V}^{*} \mathrm{P}$ & $\mathrm{TN}$ & $*$ & $\mathrm{TN}$ & $\mathrm{TN}$ \\
\hline - $\quad \mathrm{B}^{*} \mathrm{~V} * \mathrm{P}$ & $\mathrm{TN}$ & $\mathrm{TN}$ & $\mathrm{TN}$ & $\mathrm{TN}$ \\
\hline
\end{tabular}

Keterangan (notes):

$\mathrm{P} 1=$ Pemupukan NPK 100\% dosis standar $(P 1=$ NPK 100\% standard dosages $) ; \mathrm{P} 2=$ Pupuk hayati + NPK $100 \%$ dosis standar $(P 2=$ Biofertilizer $+N P K 100 \%$ standard dosages $) ; \mathrm{P} 3=$ Pupuk hayati + NPK $75 \%$ dosis standar $(P 3=$ Biofertilizer + NPK 75\% standard dosages $) ; \mathrm{P} 4=$ Pupuk hayati + NPK 50\% dosis standar $(P 4=$ Biofertilizer + NPK $50 \%$ standard dosages).

* Beda nyata pada $P \leq 0,05$ (significant at the $P \leq 0.05$ probability level)

**Beda sangat nyata (significant at the $P \leq 0,01$ probability level)

$\mathrm{TN}=$ Tidak beda nyata pada $P \leq 0,05$ (no significant differences at $P \leq 0.05$ ) 
polong kedelai VUB pada perlakuan pemupukan P2 tidak berbeda nyata dengan parameter yang sama pada perlakuan pemupukan lainnya. Data ini mengindikasikan bahwa penggunaan pupuk hayati yang dikombinasikan dengan penggunaan pupuk NPK sampai dengan 50\% dosis standar (P4) terbukti efektif dalam menghemat penggunaan pupuk NPK, karena produktivitas kedelai yang diperoleh sama dengan perlakuan pupuk $100 \%$ dosis standar.

Keragaan pertumbuhan kedelai VUB Anjasmoro, Argomulyo dan Grobogan yang ditanam di lahan rawa pasang surut mengindikasikan pula bahwa untuk optimasi produksi kedelai di lahan tersebut, disamping aplikasi teknis budidaya jenuh air, pemilihan varietas dan teknik pemupukan yang tepat dapat meningkatkan efektivitas budidaya kedelai. Dari ketiga varietas kedelai yang diuji, Anjasmoro dan Argomulyo dinilai lebih adaptif terhadap kondisi lahan pasang surut. Ghulamahdi (2011) juga melaporkan kedelai VUB Anjasmoro mampu berproduksi secara baik di lahan rawa pasang surut.

\section{Keragaan produksi dan bobot biji kedelai}

Produksi kedelai Anjasmoro dan Argomulyo dengan pemberian pupuk hayati yang dikombinasikan dengan perlakuan P3 dan P4 lebih baik dibandingkan dengan kedelai Grobogan pada perlakuan P1 dan P2, khususnya pada petak aplikasi teknis budidaya jenuh air (B2). Rata-rata produksi biji kering ketiga VUB kedelai pada petak kelompok II didapatkan lebih tinggi dan berbeda sangat nyata $(\mathrm{p} \leq 0,01)$ dengan produksi biji kering pada kelompok I dan III (Tabel 3). Produksi biji kering kedelai VUB Anjasmoro dan Argomulyo khususnya yang diberi perlakuan pupuk hayati yang dikombinasikan dengan NPK (P2, P3 dan P4) di petak utama B2 (budidaya jenuh air) pada kelompok II relatif tinggi, masingmasing 2,626 - 2,989 kg/ha dan 2,387 - 2,610 $\mathrm{kg} / \mathrm{ha}$. Kondisi jenuh air yang lebih stabil (hasil pemantauan di lapangan), dimana kehilangan air melalui rembesan dan perkolasi dari petak kelompok II pada percobaan di musim kemarau tersebut lebih mudah dikendalikan, disebabkan petak-petak percobaan kelompok II yang dikelilingi oleh petak-petak percobaan kelompok I dan III, ialah alasan utama penyebab pertumbuhan dan produksi kedelai VUB, khususnya varietas Anjasmoro dan Argomulyo lebih baik pada kelompok II. Produksi kedelai pada petakan tersebut khususnya varietas Anjasmoro, lebih tinggi jika dibandingkan dengan dengan penelitian Ghulamahdi (2011) pada varietas yang sama dengan menggunakan teknik budidaya jenuh air tetapi tanpa menggunakan pupuk hayati.

Rata-rata bobot 100 butir biji kedelai varietas Anjasmoro dan Argomulyo pada perlakuan B2 juga lebih baik dibandingkan pada perlakuan B1 (Gambar 1). Hasil biji varietas Anjasmoro dan Argomulyo pada perlakuan B2 masing-masing $174,5 \%$ dan $136 \%$ lebih tinggi jika dibandingkan dengan hasil biji varietas yang sama pada perlakuan B1. Data ini mendukung hasil yang dilaporkan Indradewa et al., (2004) dan Ghulamahdi et al., (2006) bahwa teknis budidaya jenuh yaitu dengan penggenangan air di dalam parit pada tinggi muka air $15 \mathrm{~cm}$, dapat meningkatkan kadar protein daun dan biji serta bobot biji. Sementara itu pengaruh kedua perlakuan terhadap hasil dan bobot 100 biji kedelai VUB Grobogan, tidak terlihat (Gambar 1).

Menurut Ghulamahdi et al., (1991) pada budidaya jenuh air, varietas dengan masa panen lebih pendek seperti Grobogan (panen 76 HST) akan tumbuh kurang baik, produksi lebih rendah apabila dibandingkan dengan varietas lain yang memiliki umur panen lebih panjang seperti Argomulyo (panen 86 HST) dan Anjasmoro (90 HST). Suhartina (2005) melaporkan bahwa masa panen ketiga varietas yang diuji dalam penelitian ini berbeda. Varietas Anjasmoro cenderung membutuhkan masa panen paling lama yaitu 82,5 - 92,5 hari, varietas Argomulyo 80 - 82 hari dan varietas Grobogan cenderung lebih cepat yaitu \pm 76 hari.

Penggunaan pupuk hayati dengan bahan aktif bakteri B. japonicum R6 dan A. punctata RJM 3020 dapat meningkatkan efisiensi penggunaan pupuk NPK. Aplikasi pupuk hayati dalam kombinasinya dengan NPK $50 \%$ dari dosis standar (P4) pada budidaya jenuh air mampu mendukung pertumbuhan kedelai VUB, khususnya varietas Anjasmoro dan Argomulyo. Tingkat produksi yang dicapai kedua varietas ini setara dengan penggunaan pupuk NPK 100\% dosis standar (P1) maupun aplikasi pupuk hayati yang di-kombinasikan dengan NPK 100\% (P2) dan $75 \%$ (P3) dari dosis standar. Hal itu diindikasikan oleh hasil biji kering pada perlakuan tersebut yang tidak berbeda nyata dengan hasil kedelai pada perlakuan kombinasi pupuk hayati dengan dosis pupuk $\mathrm{N}$ yang lebih tinggi pada perlakuan P2 dan P3.

Hal ini juga dikemukakan Hungria et al., (2006) dan Cassan et al., (2009) yang menyatakan bahwa fiksasi $\mathrm{N}_{2}$ secara biologi oleh $B$. japonicum merupakan cara terbaik untuk mencapai efisiensi pemupukan $\mathrm{N}$ untuk tanaman kedelai. Demikian pula penggunaan A. punctata RJM 3020 yang memiliki kemampuan menghasilkan asam organik dan enzim fosfatase yang dapat meningkatkan kelarutan P terfiksasi di dalam tanah (Goenadi et al., 2005; Goenadi \& Santi, 2009; Stella \& Syahren, 2016). 
Tabel 3. Hasil biji kering (kg/ha) tiga kedelai VUB pada masing-masing ulangan yang dipengaruhi oleh perlakuan teknis budidaya (B) dan pemupukan (P) di lahan rawa pasang surut Lampung Selatan.

Table 3. Yield of three soybean superior varieties $(\mathrm{kg} / \mathrm{ha}$ ) on each replications affected by cultivation and fertilization treatments in the tidal swampland in South Lampung.

\begin{tabular}{|c|c|c|c|c|c|c|}
\hline \multirow[t]{2}{*}{$\begin{array}{c}\text { Budidaya (Cultivation) } \\
\text { (B) }\end{array}$} & \multirow[t]{2}{*}{$\begin{array}{c}\text { Varietas } \\
\text { (Varieties) } \\
(\mathrm{V})\end{array}$} & \multirow[t]{2}{*}{$\begin{array}{c}\text { Pemupukan } \\
\text { (Fertilizing) } \\
(\mathrm{P})\end{array}$} & \multicolumn{3}{|c|}{$\begin{array}{l}\text { Hasil }(\mathrm{kg} / \mathrm{ha}) \\
\text { [Yield }(\mathrm{kg} / \mathrm{ha}) \text { ] }\end{array}$} & \multirow[t]{2}{*}{$\begin{array}{l}\text { Rata-rata } \\
\text { (Average) }\end{array}$} \\
\hline & & & I & II & III & \\
\hline Cara petani & Anjasmoro & P1 & 876 & 1.086 & 1.045 & $1.080,3$ \\
\hline \multirow[t]{11}{*}{ (Farmers method) (B1) } & & P2 & 416 & 1.523 & 717 & $1.001,3$ \\
\hline & & P3 & 581 & 1.628 & 739 & 745,7 \\
\hline & & $\mathrm{P} 4$ & 324 & 1.014 & 1034 & 772,0 \\
\hline & Argomulyo & P1 & 876 & 1.086 & 1.045 & $1.002,3$ \\
\hline & & $\mathrm{P} 2$ & 416 & 1.523 & 717 & 885,3 \\
\hline & & P3 & 581 & 1.628 & 739 & 982,7 \\
\hline & & $\mathrm{P} 4$ & 324 & 1.014 & 1.034 & 790,7 \\
\hline & Grobogan & P1 & 468 & 954 & 562 & 661,3 \\
\hline & & $\mathrm{P} 2$ & 672 & 1.530 & 601 & 934,3 \\
\hline & & P3 & 510 & 825 & 805 & 713,3 \\
\hline & & $\mathrm{P} 4$ & 359 & 993 & 560 & 637,3 \\
\hline \multirow{12}{*}{$\begin{array}{l}\text { Budidaya jenuh air } \\
\text { (saturated soil) (B2) }\end{array}$} & Anjasmoro & $\mathrm{P} 1$ & 995 & 2.325 & 1.686 & $1.668,7$ \\
\hline & & P2 & 735 & 2.626 & 928 & $1.429,7$ \\
\hline & & P3 & 560 & 2.989 & 1.004 & $1.517,7$ \\
\hline & & $\mathrm{P} 4$ & 924 & 2.798 & 1.273 & $1.665,0$ \\
\hline & Argomulyo & $\mathrm{P} 1$ & 532 & 1.612 & 1.127 & $1.090,3$ \\
\hline & & $\mathrm{P} 2$ & 544 & 2.610 & 551 & $1.235,0$ \\
\hline & & P3 & 489 & 2.387 & 681 & $1.185,7$ \\
\hline & & $\mathrm{P} 4$ & 665 & 2.397 & 1.340 & $1.467,3$ \\
\hline & Grobogan & P1 & 468 & 596 & 660 & 574,7 \\
\hline & & P2 & 469 & 604 & 699 & 590,7 \\
\hline & & P3 & 458 & 667 & 715 & 613,3 \\
\hline & & P4 & 558 & 479 & 918 & 651,7 \\
\hline
\end{tabular}

Bobot $100 \mathrm{Biji}(100$-seed weight) (g) Var. Anjasmoro

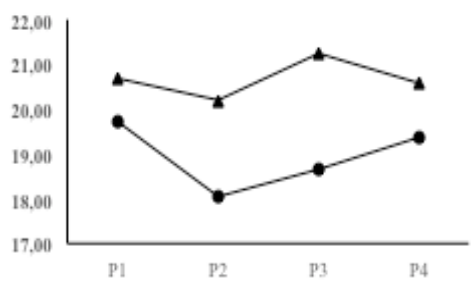

Bl=Cara Petani (Farmers method)

$\downarrow_{\text {B2}}=$ Budidaya Jenuh Air (Saturated soil)
Bobot 100 biji (100-seed Weight ) (g) Var. Argomulyo

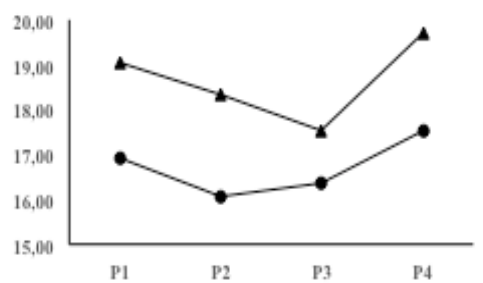

B1=Cara Petani (Farmers method)

B2=Budidaya Jenuh Air (Saturated soil)
Bobot 100 biji (100-seed Weight $(\mathrm{g})$ Var. Grobogan

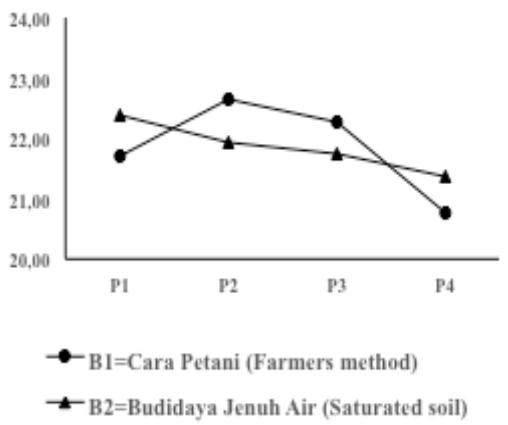

Gambar 1. Rata-rata bobot 100 biji (g) kedelai Anjasmoro, Argomulyo dan Grobogan pada perlakuan teknis budidaya cara petani (B1) dan budidaya jenuh air (B2) dengan perlakuan pemupukan yang berbeda (P1, P2, P3 dan P4).

Figure 1. Average 100-seed weight ( $g$ ) of soybean superior varieties of Anjasmoro, Argomulyo dan Grobogan at the treatments by farmers method (B1) and saturated soil (B2) with different fertilizing treatments (P1, P2, P3 and $P 4)$.

Pengaruh perlakuan terhadap kadar $C, N, P$ dan $K$ di dalam tanah.

Ketersediaan hara di dalam tanah masam seperti tanah sulfaquepts di lahan pasang surut ialah kategori rendah (Imanudin \& Armanto, 2012). Ketersediaan hara tanah Sulfaquepts yang cenderung terus menurun diantaranya dapat diatasi dengan menghindari drainase berlebihan dan mengaplikasikan teknis budidaya jenuh air (Imanudin et al., 2009).

Hasil analisis kandungan $\mathrm{C}, \mathrm{N}, \mathrm{P}$ dan $\mathrm{K}$ untuk contoh tanah yang diperlakukan dengan pupuk 

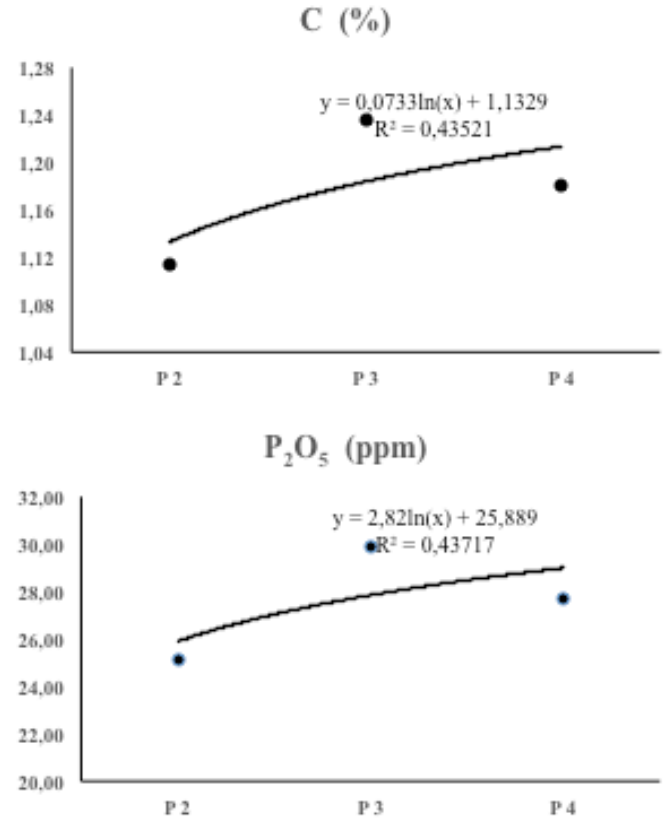

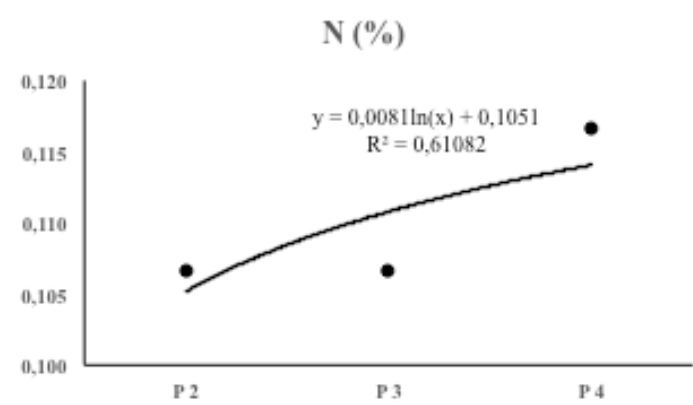

K-dd (cmol/Kg)

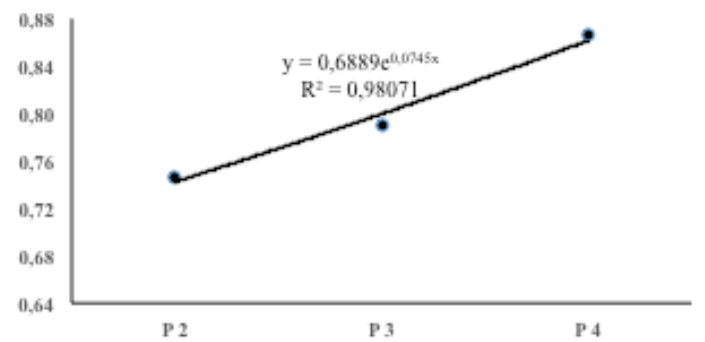

Gambar 2. Rata-rata kandungan C, N, P dan K di dalam tanah sebagai pengaruh dari perlakuan penggunaan pupuk hayati yang dikombinasikan dengan NPK 100\% (P2), 75\% (P3) dan 50\% (P4) dari dosis standar.

Figure 2. Average content of $C, N, P$ and $K$ in soil as the effect of the biofertilizer treatments combined with NPK of $100 \%$ (P2), $75 \%$ (P3), and $50 \%(P 4)$ of standard dosages.

hayati yang dikombinasikan dengan dosis pupuk NPK berbeda (P2, P3 dan P4) memperlihatkan ketersediaan jenis hara tersebut cenderung meningkat dengan penurunan aplikasi dosis pupuk NPK (Gambar 2). Indikasi ini dipengaruhi oleh aktivitas mikroorganisme tanah (Lalfakzuala et al., 2008; Mohammadi \& Sohrabi 2012). Sementara salah satu faktor yang mempengaruhi aktivitas mikroorganisme di dalam tanah adalah penggunaan pupuk kimia (Deng \& Tabatabai 1997; Klose et al., 1999) dan yang paling berpengaruh adalah $\mathrm{N}$ karena aplikasi $\mathrm{N}$ dosis tinggi seperti pada perlakuan P2 dapat menurunkan populasi mikroorganisme menguntungkan di dalam tanah (Barabasz et al., 2002).

Aplikasi $\mathrm{N}$ dosis tinggi pada perlakuan $\mathrm{P} 2$, membuat perkembangan $B$. japonicum R6 dan $A$. . punctata RJM 3020 serta mikroorganisme tanah lainnya terganggu sehingga mempengaruhi ketersediaan hara $\mathrm{C}, \mathrm{N}, \mathrm{P}$ dan $\mathrm{K}$ pada perlakuan tersebut. Pada perlakuan $\mathrm{N}$ dosis lebih rendah (P3 dan P4), diperkirakan $B$. japonicum R6 akan lebih aktif melakukan nodulasi dan penambatan $\mathrm{N}_{2}$ udara (Cassan et al., 2009). Fosfor tersedia meningkat karena aktivitas bakteri Aeromonas punctata RJM 3020 dapat meningkatkan pelarutan $\mathrm{P}$ terfiksasi didalam tanah. Peningkatan $\mathrm{K}$ dapat dipertukarkan di dalam tanah mungkin dapat pula disebabkan karena perkembangan aktivitas mikroorganisme di dalam tanah (Araujo et al., 2009; Yamashita et al., 2013; Singh et al., 2010; Parmar \& Sindhu, 2013).

\section{Kesimpulan}

Jenis varietas unggul baru kedelai yang sesuai untuk budidaya kedelai di lahan sawah pasang surut di daerah Lampung Selatan berdasarkan hasil penelitian ini adalah varietas Anjasmoro dan Argomulyo. Penggunaan pupuk hayati dengan bahan aktif bakteri $B$. japonicum R6 dan $A$. punctata RJM 3020 yang dikombinasikan dengan penerapan teknis budidaya jenuh air dapat mengurangi dosis pupuk NPK sampai dengan $50 \%$. Teknik ini dapat meningkatkan produksi kedelai masing-masing sebesar 35,1\% (Arjasmoro) dan 31,7\% (Argomulyo) jika dibandingkan dengan teknik bididaya petani saat ini dan penggunaan pupuk NPK $100 \%$ dari dosis standar. Penggunaan pupuk hayati untuk tanaman kedelai varietas Anjasmoro dan Argomulyo di dalam suatu sitem budidaya jenuh air dalam penelitian ini yang dikombinasi dengan pupuk NPK $50 \%$ dapat menghasilkan produksi biji tertinggi masing-masing 2,798 $\mathrm{kg}$ biji/ha (Anjasmoro) dan 2,397 kg biji/ha (Agromulyo).

\section{Ucapan Terima Kasih}

Penelitian dilaksanakan dengan dana APBN di dalam DIPA Tahun Anggaran 2015, Balai Pengkajian Teknologi Pertanian (BPTP) Lampung, Badan Penelitian dan Pengembangan Pertanian, Kementerian Pertanian RI. 


\section{Daftar Pustaka}

Achmadi \& I Las (2006). Inovasi teknologi pengembangan pertanian lahan rawa lebak. Seminar Nasional Inovasi Teknologi dan Pengembangan Terpadu Lahan Rawa Lebak, p. 21-36. http://balittra.litbang. pertanian.go.id /prosiding06/Utama-3.pdf. [5 Apr 2016]

Amel B, T Sihem, OS Mohamed \& B Abdelkader (2014). Effects of inoculation by Bradyrhizobium japonicum strains on nodulation, nitrogen fixation, and yield of lablab purpureus in Algeria. Turkish Journal of Agricultural and Natural Sciences Special Issue 2, 1870-1876.

Andriesse, JP (1988). Nature and management of tropical peat soils. Fao soils bulletin 59. Food and Agriculture Organization of the United Nations, Via delle Terme di Caracalla, 00100 Rome, Italy.

Araújo ASF, LFC Leite, VB Santos \& RFV Carneiro (2009). Soil microbial activity in conventional and organic agricultural systems. Sustainability 1, 268-276.

Bahri S, G Purwanto, B Hafif, Slameto, Widiyantoro, D Suherlan, Yusmeinardi, \& Sunaryo (2004). Pewilayahan komoditas pertanian berdasarkan agroekologi Kabupaten Lampung Selatan. Balai Pengkajian Teknologi Pertanian Lampung.

Balai Penelitian Pertanian Lahan Rawa (2012). Lahan rawa, solusi krisis kedelai. http://balittra.litbang.pertanian.go.id/index.php option=com_content\&view $=$ article\&id $=189 \&$ Itemid=10. [10 Mar 2015].

Barabasz W, D Albińska, M Jaśkowska \& J Lipiec (2002). Biological effects of mineral nitrogen fertilization on soil microorganisms. Polish Journal of Environmental Studies, 11 (3), 193-198.

Cassan F, D Perrig, V Sgroy, O Masciarelli, C Penna \& V Luna (2009). Azospirillum brasilense Az39 and Bradyrhizobium japonicum E109, inoculated singly or in combination, promote seed germination and early seedling growth in corn (Zea mays L.) and soybean (Glycine max L). European journal of soil biology 45, 28-35.

Delaux CB, D Marburger, PM Delaux, S Conley \& JM Ané (2014). Effect of drought on Bradyrhizobium japonicum populations in Midwest soils. Plant Soil. DOI 10.1007/s11104-014-2155-0. https://www.researchgate.net/publication/2628 75574 [10 Mar 2016].

Deng SP \& MA Tabtabai (1997). Effect of tillage and residue management on enzyme activities in soils. III Phosphatases and Arylsulphatases. Biol. Fert. Soils 22,208-213.

Forum for Nuclear Cooperation in Asia (2005). Brief information on biofertilizer studies conducted at Batan. FNCA Biofertilizer Newslatter. 6, 9-15.

Ghulamahdi M (2011) Best practice dalam budidaya kedelai di lahan pasang surut. Prosiding Kongres Ilmu Pengetahuan Nasional (Kipnas) X Tahun 2011. Jakarta $8-10$ November 2011.

Ghulamahdi M, F Rumawas, J Wiroatmojo \& J Koswara (1991). Pengaruh pemupukan fosfor dan varietas terhadap pertumbuhan dan produksi kedelai pada budidaya jenuh air. Forum Pascasarjana 14(1), 25-34.

Ghulamahdi M, SA Aziz, \& AK Makarim (2012). Penerapan teknologi budidaya jenuh air pada tanaman padi dan kedelai untuk meningkatkan indeks penanaman di lahan pasang surut dalam M Melati et al. (eds). Prosiding Simposium dan Seminar Bersama PERAGIPERHORTI-PERIPI-HIGI Mendukung Kedaulatan Pangan dan Energi yang Berkelanjutan. IPB ICC Bogor, 1-2 Mei 2012.

Ghulamahdi M, SA Aziz, M Melati, N Dewi \& SA Rais (2006). Pengaruh genotipe dan pupuk daun terhadap pertumbuhan dan produksi kedelai panen muda pada budidaya jenuh air. Bul. Agron. 34 (1), 32-38.

Ghulamahdi M, M Melati \& D Sagala (2009). Production of soybean varieties under saturated soil culture on tidal swamps. $J$. Agron. Indonesia 37 (3), 226232.

Goenadi DH \& LP Santi (2009). Introduction of microbial inoculants to improve fungsional relationship between above- and belowground bio-diversity.

Goenadi DH, YT Adiwiganda \& LP Santi (2005). Development technology and comercialization of emas (Enhancing Microbial Activity in the Soils) biofertilizer. FNCA Biofertilizer Newslatter. 6, 2-4.

Haryono (2013). Lahan rawa lumbung pangan masa depan Indonesia. Badan Penelitian dan Pengembangan Pertanian. IAARD PRESS, $142 p$. 
Hungria M, JC Francini, CC Crispino, JZ Moraes, RNR Sibaldelli, \& J Arihara (2006). Nitrogen nutrition of soybean in Brazil: Contributions of biological $\mathrm{N}_{2}$ fixation and $\mathrm{N}$ fertilizer to grain yield. Canadian J. Plant Sci. 86 (4), 927-939.

Imanudin MS \& E Armanto (2012). Effect of water management improvement on soil nutrient content, iron and aluminum solubility at tidal low land area. APCBEE Procedia 4, 253-258.

Imanudin MS, RH Susanto, E Armanto \& SM Bernas (2009). The use of drainmod model for developinf strategic operation of water management in the tidal lowland agriculture areas of South Sumatera Indonesia. Proceeding of International Seminar on Wetland and Sustainability, Kota Kinabalu Sabah Malaysia. 26-28 Juni 2009. ISBN 478983-3142-11-8.

Indradewa, D, S Sastrowinoto, S Notohadisuwarno \& H Prabowo (2004). Metabolisme nitrogen pada tanaman kedelai yang mendapat genangan dalam parit. Bul. Agron 11 (2), 68-75.

Ismawi S, MS Gandaseca \& OH Ahmed (2012). Effects of deforestation on soil major macronutrient and other selected chemical properties of secondary tropical peat swamp forest. Int. J. Phy. Scie. 7 (14), 2225 - 2228.

Klubeck BP, LL Hendrickson, RM Zablotowicz, JE Skwara, EC Varsa, S Smith, TG Isleib, J Maya, M Aldes, FB Dazzo, RL Todd \& DD Walgenback (1988). Competitiveness of selected Bradyrhizobium japonicum strains in midwestern USA soils. Soil Sci. Soc. Am. J. 52, 662-666.

Klose S, JM Moore \& MA Tabatabai (1998). Arylsulphatase activity of microbial biomass in soils as affected by cropping systems. Boil. Fert. Soils 29, 46-54.

Könönen, M, J Jauhiainen, R Laiho, K Kusin \& H Vasander (2015). Physical and chemical properties of tropical peat under stabilised land uses. Mires and Peat 16, 1-13.

Lakitan B \& N Govar (2013). Kebijakan inovasi teknologi untuk pengelolaan lahan suboptimal berkelanjutan. Dipresentasikan pada Seminar Nasional Lahan Sub-optimal, Palembang, 20-21 September 2013.

Lalfakzuala, R, K Kayang \& MS Dkhar (2008). The effect of fertilizer on soil microbial component and chemical properties under leguminous cultivation. American-Eurusian J. Agric. Environt. Sci, 3 (3), 314-324.

Mohammadi K \& Y Sohrabi. (2012). Bacterial biofertilizers for sustainable crop production: A review. ARPN Journal of Agricultural and Biological Science 7 (5), 307-316.

Nazemi D, A Hairani \& Nurita (2012). Optimalisasi pemanfaatan lahan rawa pasang surut melalui pengelolaan lahan dan komoditas. Agrivigor 5 (1), 52-57.

Nurhayati, Nuryadi, Basuki \& Indawansani (2010). Analisis karakteristik iklim untuk optimalisasi produksi kedelai di Provinsi Lampung. Laporan Akhir Pelaksanaan Program Insentif Pkpp Ristek 2010. Pusat Penelitian dan Pengembangan Badan Meteorologi Klimatologi dan Geofisika, 80p.

Noh JG, HE Jeon, JS So \& WS Chang (2015). Effects of the Bradyrhizobium japonicum waaL ( $r f a L)$ gene on hydrophobicity, motility, stress tolerance, and symbiotic relationship with soybeans. Int. J. Mol. Sci. 16, 1677816791.

Parmar P \& SS Sindhu (2013). Potassium solubilization by rhizosphere bacteria: influence of nutritional and environmental conditions. J. Microbiol. Res. 3(1), 25-31.

Simanungkalit RDM (2001). Aplikasi pupuk hayati dan pupuk kimia: suatu pendekatan terpadu. Buletin AgroBio 4(2), 56-61.

Singh G, DR Biswas \& TSM Arwah (2010). Mobilization of potassium from waste mica by plant growth promoting rhizobacteria and its assimilation by maize (Zea mays) and wheat (Triticum aestivum L.). J. Plant Nut. 33, 1236-1251.

Stella M \& AM Syahren (2016). Application of phosphate solubilising microorganisms to increase the solubilisation of rock phosphates in soil. J. Trop. Agric. and Fd. Sc. 44(1), $9-$ 18.

Sudaryanto B, G Purwanto, D Suherlan \& Yusmeinardi (2002). Zonasi agroekologi Provinsi Lampung. Balai Pengkajian Teknologi Pertanian Lampung, 22p.

Suhartina (2005). Deskripsi varietas unggul kacang-kacangan dan umbi-umbian. Balai Penelitian Tanaman Kacang-kacangan dan Umbi-umbian. 154 p. 
Sukarman, Risfaheri, B Hafif \& Hapid (2013). Peta zona agroekologi Provinsi Lampung skala 1:250.000. Kementerian Pertanian.

Sulaeman, Suparto \& Eviati (2005). Petunjuk teknis analisis kimia tanah, tanaman, air, dan pupuk. Balai Penelitian Tanah, 136p.
Yamashita K, H Honjo, M Nishida, M Kimura \& S Asakawa (2013). Estimation of microbial biomass potassium in paddy field soil. Soil Sci.Plant Nut. 60, 512-519. 